\title{
ACROTHECIUM LEAF SPOT OF BASELLA RUBRA L.
}

\author{
BY L. A. ALVAREZ GARCIA
}

Phytopathologist, Agricultural Experiment Station, Rio Piedras, Puerto Rico

Basella rubra L. (B. alba L.), known commonly as Malabar Nightshade in Asia and "Espinaca del País" in Puerto Rico, is a succulent annual or biennial vine of Asiatic origin. It is grown in Puerto Rico and in other regions of the Caribbean area for its edible foliage composed of alternate, entire leaves.

At present, there is only a small acreage planted in Puerto Rico. Some few acres are grown to supply public school lunchrooms. Vines are sometimes seen growing on home gardens. This plant can supply a steady and cheap crop of leaves throughout the entire year. The succulent leaves can be used green or cooked, being more appetizing in the latter manner.

The small acreage of th crop in Puerto Rico is to be attributed to the lack of knowledge among farmers of the advantage of having a cheap source of greens for home consumption the year round. It is a well known fact that one of our great dietary problems in Puerto Rico is the insufficiency of roughage in our meals. Vegetable growing in Puerto Rico is a risky proposition and an expensive one for the average farmer. The small farmers could solve in part their roughage problem by a more liberal use of this fast-growing crop. A few plants suffice to take care of the family needs.

A review of the available literature reveals but very few organisms attacking Basella rubra L. From Brazil (9); three leaf parasites causing appreciable damage to this plant have been reported: A Stagonospora, a Cercospora and a Phyllosticta species.

In Puerto Rico the writer observed a severe leaf spotting of $B$. rubra among plants grown in a vegetable garden of the W.P.A. (Work Project Administration), located at the Experimental Station grounds, at Río Piedras, P. R. The serious outbreak occurred during the hot, humid summer of 1943.

The disease was characterized by numerous, reddish, subcircular leaf lesions and reddish, elongate vine spots. A parasitic fungus of the genus Acrothecium was almost invariably isolated from the red leaf and vine lesions. This organism has never been reported in Puerto Rico nor apparently elsewhere; hence research was conducted to elucidate the hostparasite relationship, under our environment, in the hope of finding a practical measure of control of the disease.

THE DISEASE

The disease caused most serious damage to the foliage, impairing its food value. Primary infections of leaves appeared as a few small yellowish- 
brown or reddish spots which enlarged slowly when weather conditions were relatively dry. Leaf spots sometimes showed yellowish, marginal zones, but the affected area remained sharply defined. When the enlargement of the leaf lesions was arrested, a distinctive reddish halo was formed around the innermost, necrotic dirty-brown leaf tissues of the lesions.

During periods of humid atmospheric conditions, the number of leaf and vine lesions was very large, the leaf spots enlarged very rapidly and in many instances the enlarging spots coalesced and formed great patches of necrotic tissues. Such rapidly enlarging spots failed in many occasions to form the characteristic reddish halo observed in lesions with arrested growth.

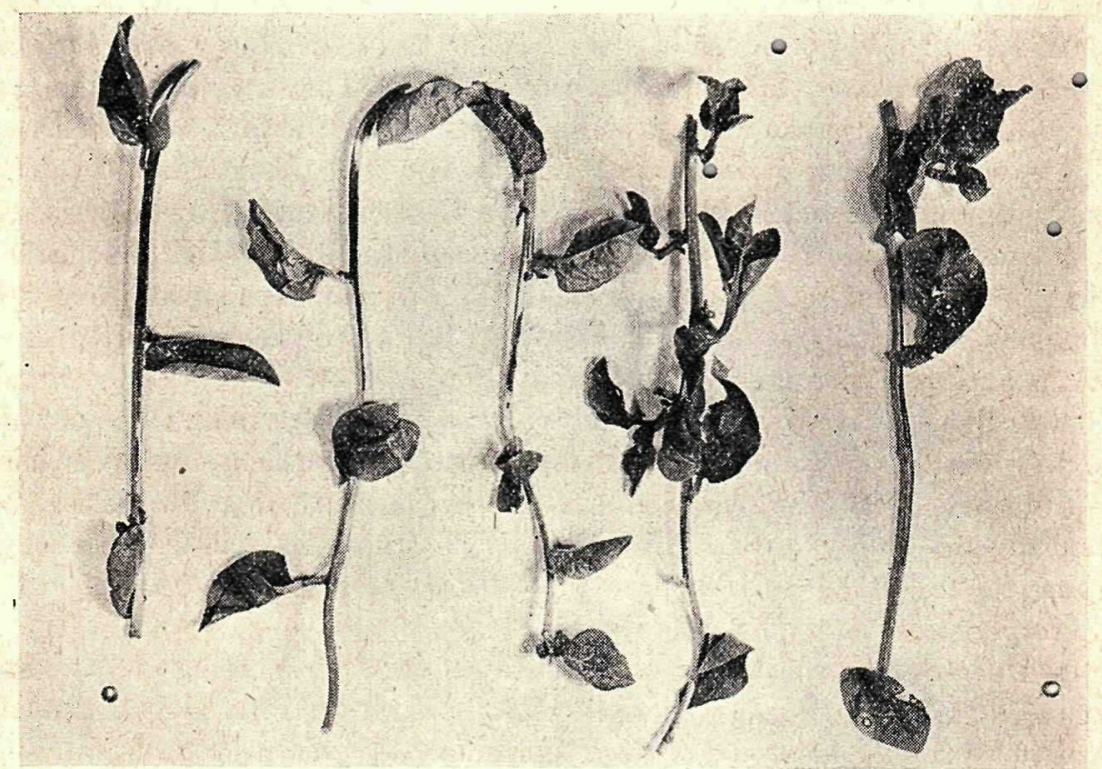

FIg. 1. Natural infections on cuttings of Basella rubra L. showing leaf and vine lesions caused by Acrothecium basellae. Size greatly reduced.

Leaf lesions were frequently observed developing near the leaf margins, and particularly near the tips. If near each other, the lesions coalesced and enlarged toward the midrib. With the progress of the disease the leaf margins became ragged. Severely affected leaves became chlorotic, the yellowing invading nearby necrotic leaf areas and extending throughout the blade. Such severely infected leaves abscised. Affected leaves showed pronounced curling and sometimes rolling. Young as well as mature leaves were found very susceptible to the disease, although more so in muggy weather (Fig. 1).

Vines of infected plants at first showed very small reddish lesions similar 
to those already described occurring on leaves. In dry weather, the lesions enlarged longitudinally, forming long, reddish spots which in very few cases girdled the vines. The lesions were lustrous, reddish and dry, very superficial. The parasite confined its parasitism almost entirely to the endodermal tissues of the vines, except in very muggy weather when the internal vine tissues were also involved. Under such cases of extreme humidity and hot temperature, the vine lesions were also found invaded by secondary soil organisms. A Rhizoctonia sp. was frequently isolated from Acrothecium lesions at the base of the vines or on vines running over the ground (Fig. 2).

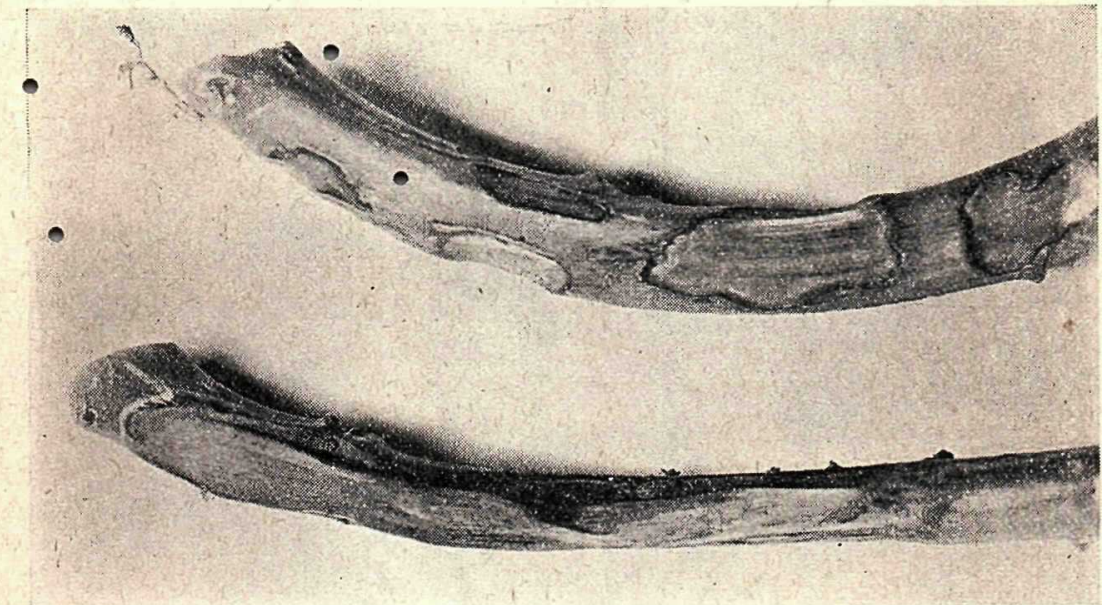

Frg. 2. Advanced lesions at base of vine of Basella rubra, caused by Acrothecium basellae. Natural size.

The secondary invasion of Acrothecium vine lesions by the saprophytic Rhizoctonia sp. culminated in a soft, mushy rot of the vines at the points of infection. Eventually the whole vines dried up.

\section{THE FUNGUS}

Taxonomy. The parasite is a species of Acrothecium, a Deuteromycete belonging to the group Dematiaceae of the Fragmosporeae (Fig. 3). This is the fifth record of an Acrothecium from Puerto Rico. In 1919, Tehon (9) described a fungus on Setaria sp., as A. flacatum. In 1930, Ashford and Ciferri (1) described under the name of $A$. obovatum subcapitulatum an organism growing saprophytically on human skin. Toro, in 1926, described the fungus $A$. polytriades occuring on leaves of Polytriades amauris L. A. capsici Turconi, was reported on Capsicum frutescens $\mathrm{L}$. 

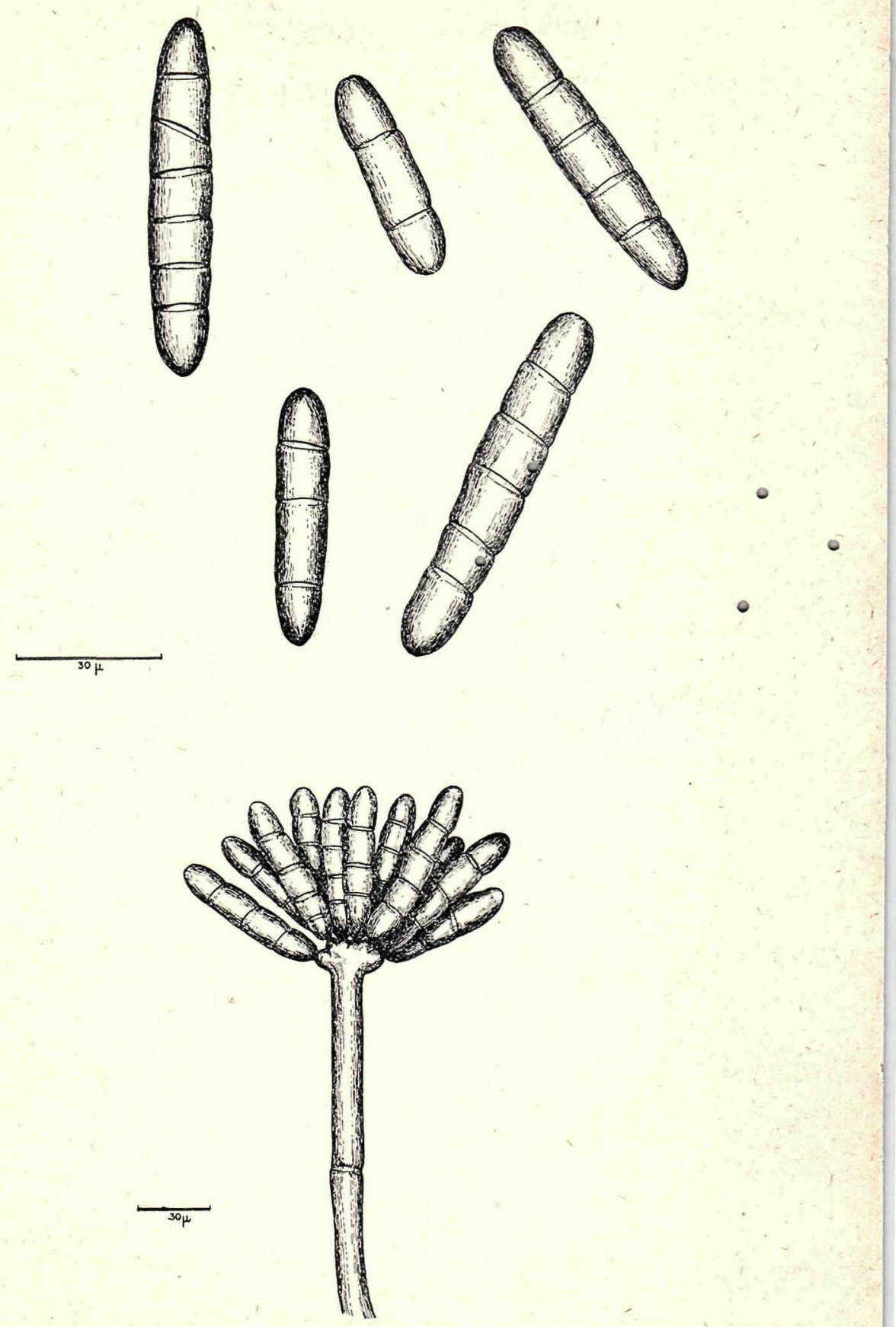

Fig. 3. Conidia of Acrothecium basellae and conidiophore the latter showing manner of sporulation. Máterial obtained from a pure culture of the organism on potato-dextrose-agar kept at $30^{\circ} \mathrm{C}$. Drawing made with camara lucida. 
Other organisms reported outside Puerto Rico are: $A$. nigrum, A. obovatum as a saprophyte on wood, $A$. lunatum Wak., growing saprophytically on sugarcane leaves, also parasitic on Panicum frumetaceum, Eleusine corocana and Setaria italica in India, and A. penniseti responsible for a leaf spot of Pennisetum Typhoideum. The morphological characters of all these organisms are different from those of the parasite described in this paper, particularly in shape and size of spores and the formation of sclerotia of the latter, a characteristic which appears to be reported here for the first time for this genus.

Many authors have recognized the necessity of revising the genus Acrothecium. They substantiate their criteria on the basis of morphological variations of organisms grouped in this genus; variations that participate in characteristics of other genera. Ashford and Ciferri (1) reported variation in cultures of $A$. obovatum subcapitulatum corresponding to such other

- genera as Brachysporum, Spondylocladium and Napicladium. They also reported that uniseptate cofidia resembled Cordana and continuous conidia Acrotheca.

Tehon (9) found similar behavior in sporulation and other characters in culture of A. facatum. Manoranjan Mitra (5) also observed in cultures of $A$. penniseti the formation of acrogenous conidia and group of conidia below the apex of the conidiophores. A. basellae, the parasite on B. rubra and the subject of this paper, produced only acrogenous, cylindric spores, conforming in these and other particulars very closely to the general characters ascribed to the genus Acrothecium.

Morphology of the fungus on the host: The mycelium consisted of subhyaline hyphae which ramified inside the host tissues, intra and intercellularly, involving the entire leaf tissues. In the vines, the mycelium was confined mostly to the endodermal cells.

Conidiophores were produced amphigenously in the central necrotic tissues of the leaf lesions, arising from sub-stomatal, sclerotia-like bodies or pushing out to the surface between dead cells. In dry conditions, few conidiophores were observed on the leaf lesions, but they were very abundant when the relative humidity of the atmosphere was high. The conidiophores were solitary, rigid or slightly bent, long-septate, very long, sometimes reaching a length of $500 \mu$ or even longer. In width, the conidiophores varied from 9 to $15 \mu$. The conidiophores were subhyaline when young and not particularly differentiated from the fruiting mycelium. In old cultures, the conidiophores turned brownish. At the apex of the long conidiophores tubercle-like sterigmata were produced in variable numbers, depending on the degree of sporulation which had occurred at the time of microscopic observation. Sterigmata when in large number, formed very conspicuous grape-like clusters. Sterigmata fluctuated from 9 to $15 \mu$ in diameter. 
Conidia were produced acrogenously, single or fasciculate as outgrowths from the sterigmata. At first, the conidia were subhyaline projections which enlarged to become long, cylindric, dark, olive-brown spores measuring from 18 to $92 \mu$ in length and from 7.5 to $15 \mu$ in width. The acrogenous conidia were found in variable number, fluctuating from 1 to 15 or perhaps more, arranged in fascicles at the apex of the conidiophores. Due to the lack of mucilage formation at the head of the conidiophores, the conidia detached easily when blowing a soft current of air over the cultures or when floating the conidiophores and their conidia in water. Conidia formation was very profuse in humid conditions. In dry conditions sporulation was not appreciable. Sporulation was easily induced when infected leaves were placed in moist chambers, spores being formed overnight.

Microscopic examination of infected leaves from plants growing in moist environment revealed a profuse mycelial development of the parasite inside the infected leaf tissues. Abundant conidia formation was noticed at the head of numerous subhyaline or dark conidiophores. Sclerotia formation was abundant in the necrotic tissues of the lesions. The sclerotia owere dark, semi-hard, composed of anastomosed, thick wall hyphae, were relatively small and not enlarging beyond $1 \mathrm{~mm}$. in diameter.

\section{CULTURES}

Pure cultures of the Acrothecium sp. were obtained by pouring dilution plates with conidia washed from infected leaves kept in moist chambers; thus inducing abundant sporulation. Owing to the large size of the spores, fishing them out of the cultures to make subcultures was an easy matter.

Germination of conidia in distilled water. Conidia placed in distilled, sterile water germinated readily within an hour or two. Germination tubes were extruded from apical and basal cells as well as from intermediate cells of the spores. One or more germ tubes were produced either from one or from various cells of the spores. The germ tubes grew very rapidly until the spore was disorganized (Fig. 4, $A$ ).

Morphology of the fungus in cultures. The parasite grew well on different culture media. Nutrient-2\% dextrose-agar was found very satisfactory for growth and sporulation. On this medium the mycelial growth was profuse, provided the $\mathrm{pH}$ values were around neutrality and the temperature relatively high. Growth of the mycelium was mostly submerged, radial subhyaline at first and later dark (Fig. $4, B, C$ ). The substratum changed gradually to brownish.

Sclerotia formation was very profuse, and those formed were imbedded in the medium. At the start of their formation the sclerotia were subhyaline, becoming dark brown at maturity; they were almost homogeneous in structure and shade, not smooth, usually single, sometimes conglom- 

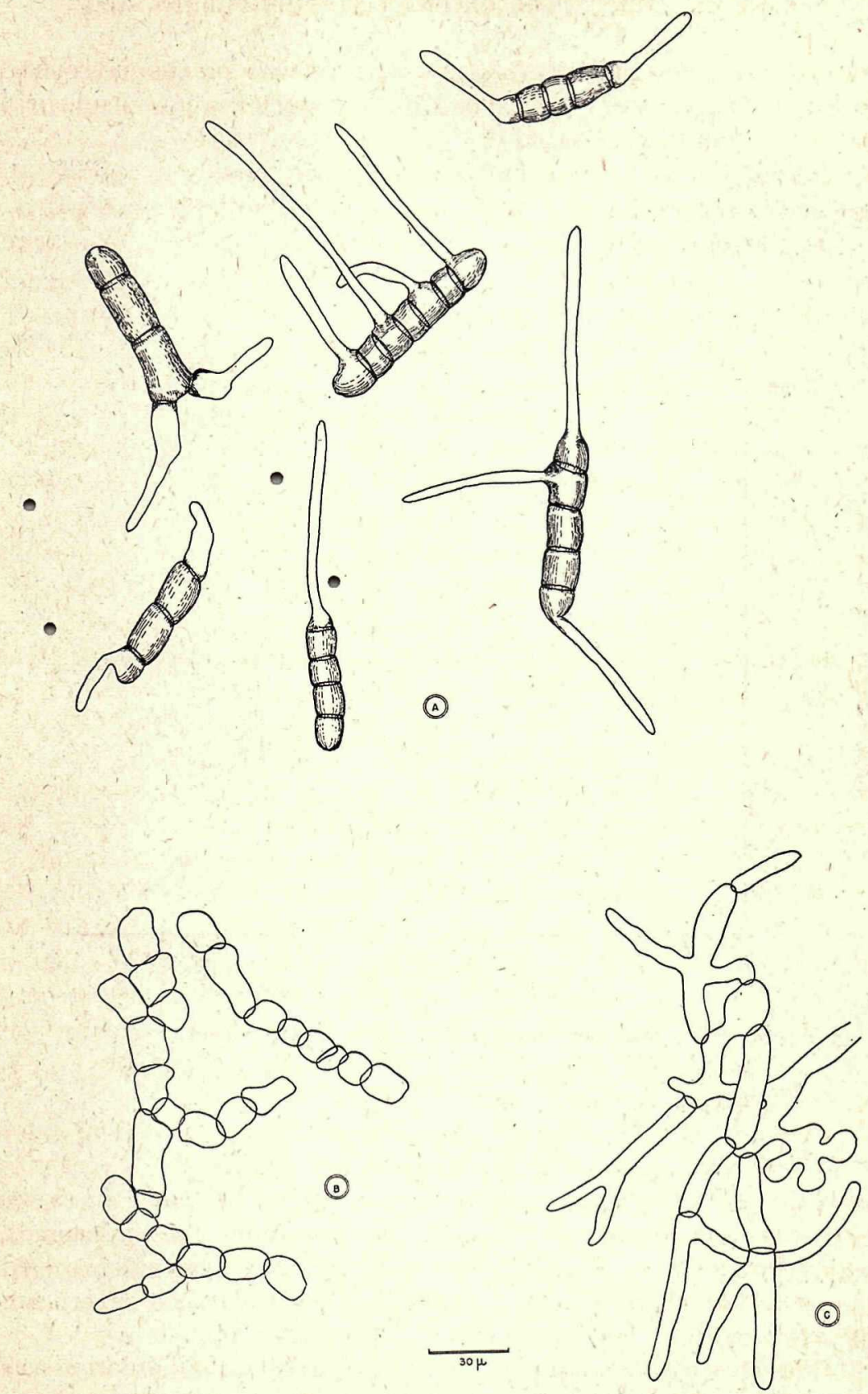

FIG. 4. Above, conidia of Acrothecium basellae germinating within three hours of being immersed in distilled water. Below, close-septate and long-septate mycelium of organism in culture. 
erated and arranged radially following the growth of the mycelium. Sclerotia fluctuated in size from 160 to $320 \mu$ in diameter, were subspherical or irregularly shaped, semi-hard.

Sporulation was very abundant, conidia being produced apically in fascicle and corresponding in size and number with those observed on natural leaf lesions. Conidia varied from 30 to $72 \mu$ by 9 to $15 \mu$, were

(A)

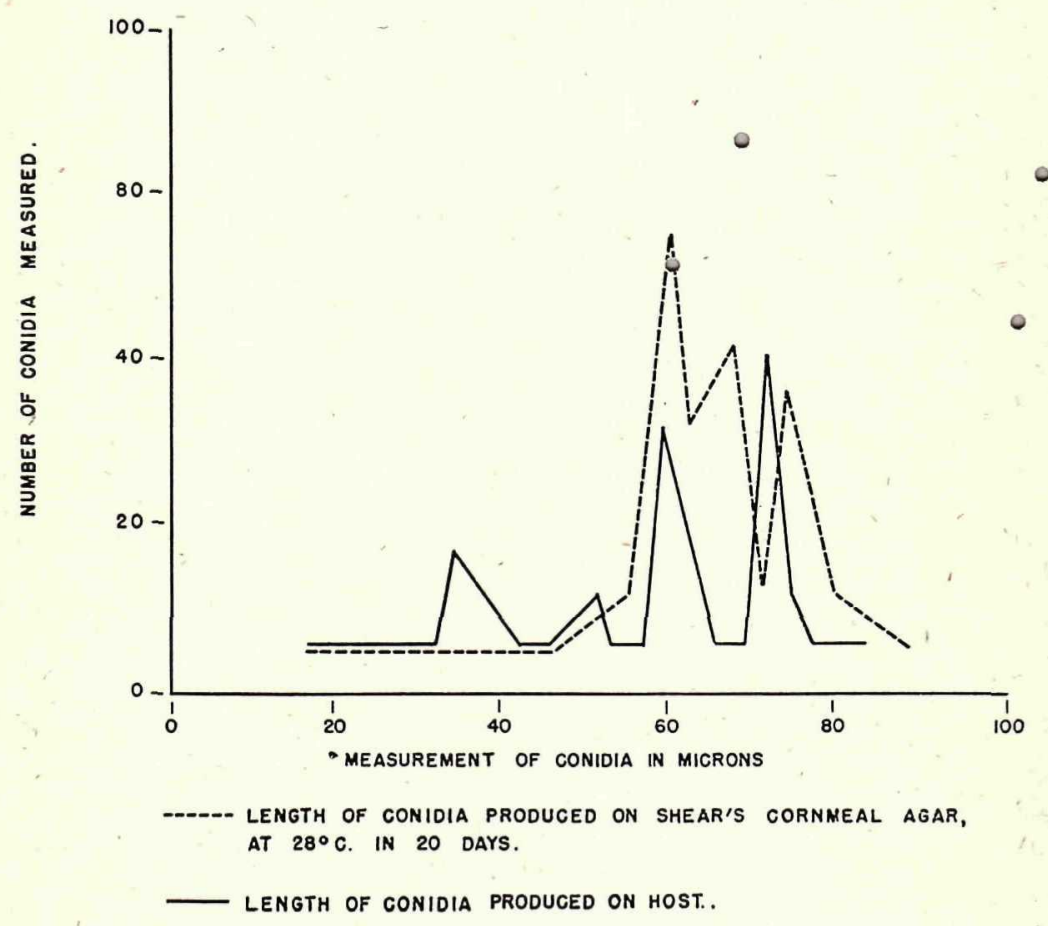

$5 \mathrm{~A}$

generally three-septate to five-septate and slightly constricted at the septa. In old cultures the hyphae became thick-walled, forming chlamydospores.

Growth of parasite on other media. On $2 \%$ dextrose-agar with an acid reaction of 6.71 and kept at $30^{\circ} \mathrm{C}$., the growth was rather poor, superficial, mostly submerged, radial, subhyaline at first, later olive-brown. Few sclerotia were formed, ranging in size from 120 to $320 \mu$. Sporulation was also poor or did not occur at all in some tubes. Spores were within range of spore measurements observed in nature.

On $2 \%$ dextrine-agar, $\mathrm{pH} 6.37$, kept at $30^{\circ} \mathrm{C}$., the growth was scanty, 
submerged, subhyaline or slightly superficial, turning later olive-brown. Sclerotia varied in size from 108 to $196 \mu$. Few spores were produced.

On cornmeal (Shear's) agar, $\mathrm{pH} 6.14$, kept at $30^{\circ} \mathrm{C}$., the mycelium was submerged or slightly superficial, scattering and radially arranged, closely septate and slightly constricted at the septa. Width of hyphae of submerged mycelium varied from 6 to $9 \mu$, septation occurred every 15 to $30 \mu$.

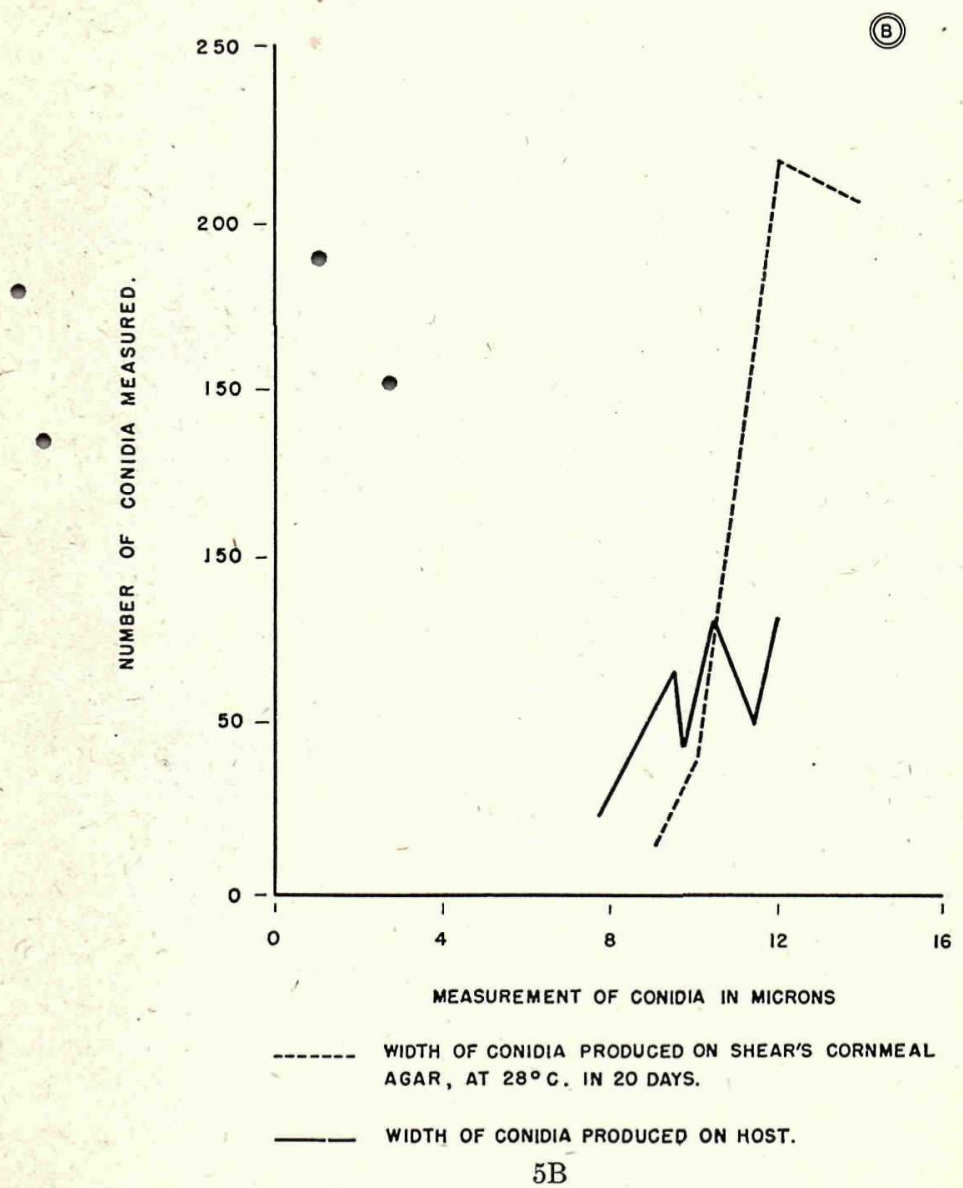

Fig. 5. Comparison of size of spores of Acrothecium basellae produced on the host and on artificial substratum.

Conidia formation was relatively abundant; conidia were one to fiveseptate, granular, and from 24 to $81 \mu$ in length by 9 to $15 \mu$ in width. Conidiophores were very long, slightly tinged brown, not abundant, and rather scattered on the medium. Sclerotia usually were produced rather singly, few in number and relatively small, varying from 45 to $105 \mu$ in size (Fig. 5). 
On $2 \%$ maltose-agar, $\mathrm{pH} 5.64$, kept at $30^{\circ} \mathrm{C}$., mycelial growth was slow, submerged and olive-brown. Spore formation was poor. Sclerotia were abundant, agglomerated, rather small.

Relation of $p H$ values of the substratum and growth. Several lots of $2 \%$ dextrose-nutrient-agar plates from the same batch, were treated with lactic acid and adjusted to varying $\mathrm{pH}$ values. A range from $\mathrm{pH} 4.27$ to $\mathrm{pH} 7.15$ was prepared; the reactions were determined by means of a potentiometer. Four plates of each set of $\mathrm{pH}$ values were respectively planted with mycelial disks, $0.5 \mathrm{~cm}$. in diameter, of the same age. Twenty four hours

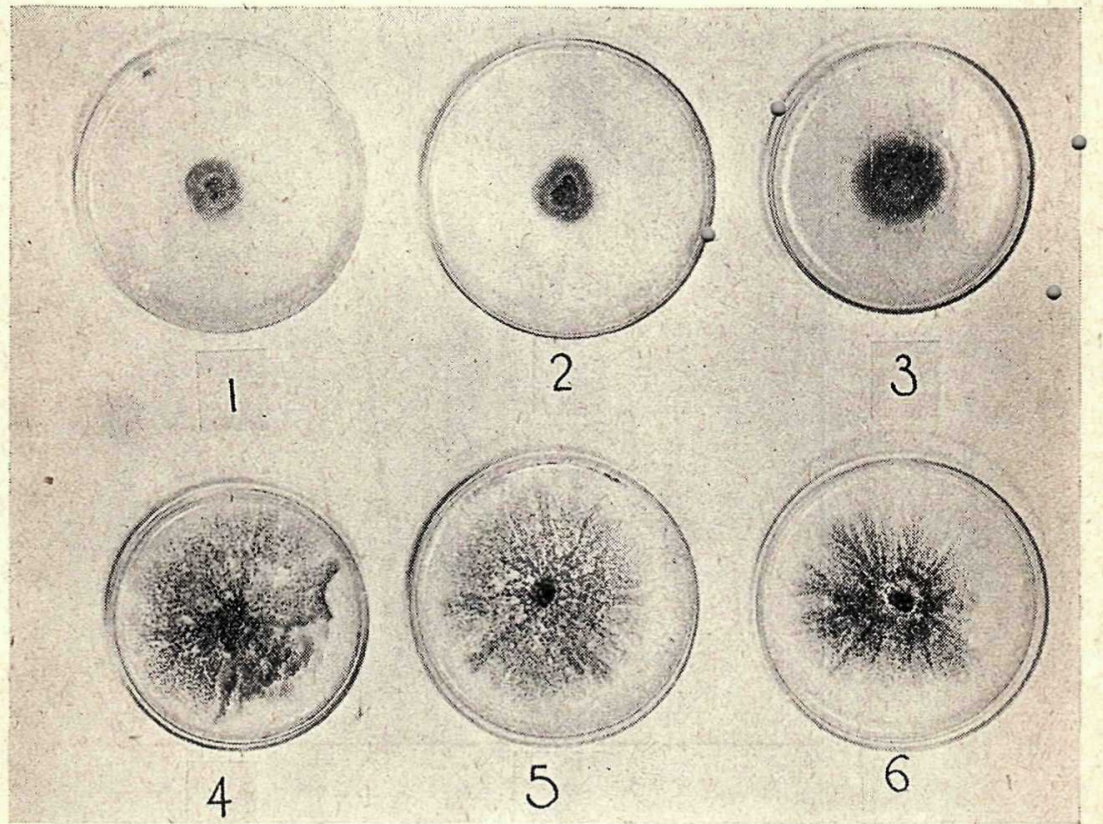

FIG. 6. Growth of Acrothecium basellae in six days on dextrose-peptone-agar adjusted to $\mathrm{pH}$ values of $4.27,4.61,5.29,5.97,6.47,7.15$, respectively. Cultures kept at $30^{\circ} \mathrm{C}$. Note abundance of sclerotia in plates 4,5 , and 6 .

increments of growth of each colony were recorded for a period of seven days. The records represented the average of two diameters of each colony taken at right angles to each other. The average of each set of four plates was jotted down as the growth rate at a given $\mathrm{pH}$ value. The results obtained showed that the parasite was favored by slight acid or alkaline reaction of the substratum (Fig. 6).

Relation of temperature and growth. Four plates containing $2 \%$ dextrosenutrient-agar, $\mathrm{pH} 7.15$, were respectively planted with $0.5 \mathrm{~cm}$. in D. mycelial disks taken from young, actively growing cultures of the parasite. 
The plates were kept for twelve hours at $28^{\circ} \mathrm{C}$., until the colonies have enlarged $2 \mathrm{~mm}$. in radial growth. The cultures were subsequently placed in lots of four in incubators set at $0,9,20,24,28,32,35$ and $37^{\circ} \mathrm{C}$. The growth rate per day of each colony was recorded as previously explained. The results obtained indicated that high temperatures favored the growth

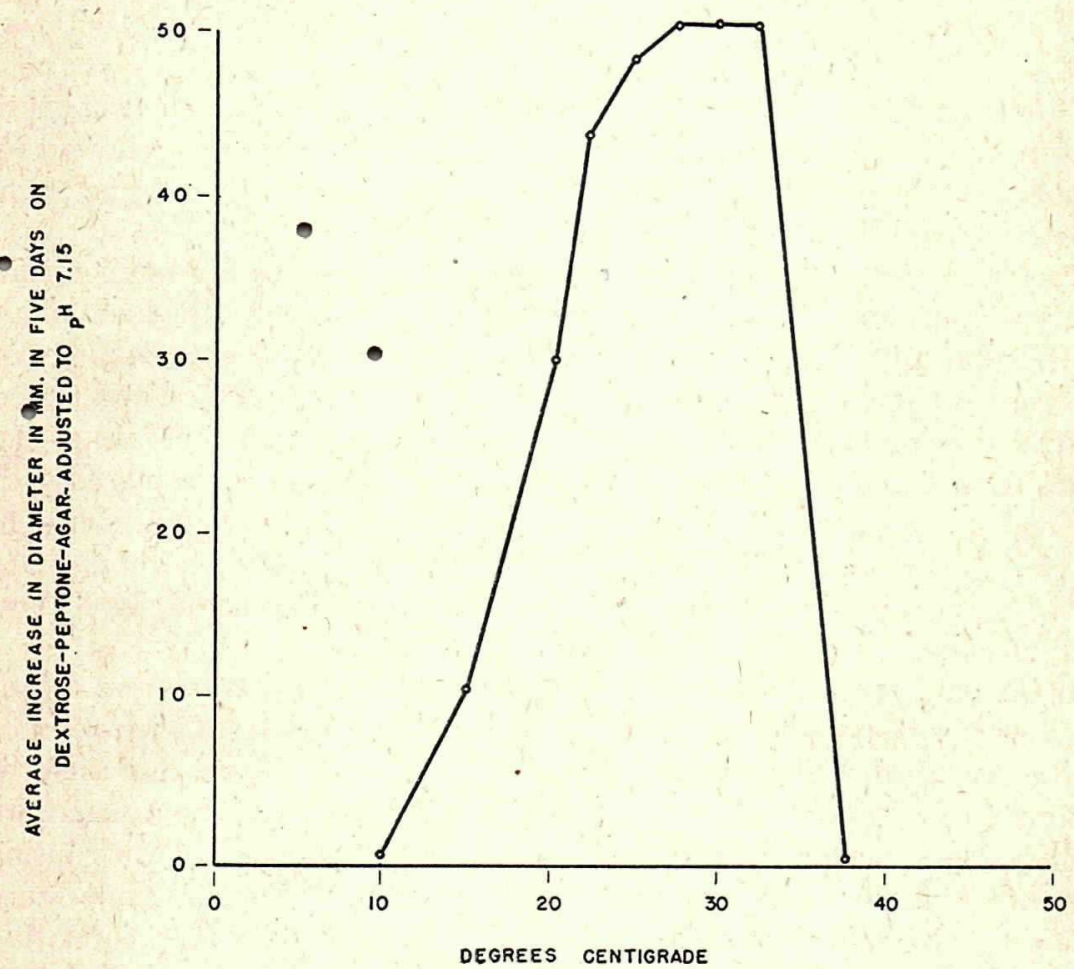

Fig. 7. Relation of temperature to growth of Acrothecium basellae

of the parasite. The fastest growth occurred at temperatures within 28 to $32^{\circ} \mathrm{C}$. (Fig. 7 ).

In view of the fact that a parasite of the genus Acrothecium attacking Basella rubra L. has not been previously reported in American and probably not in Eurasian and African literature, the present fungus is described here as a new species:

Acrothecium basellae sp. nov.:

Conidiophores amphigenous, rigid, erect or subdecumbent, simple, 3 to 5 septate, solitary or sometimes fasciculate; apex swollen with numerous tubercle-like sterig- 
mata, subhyaline at first, later olive-brown, not differentiated from the fertile hyphae, except for its long septation and swollen head, length of conidiophores more or less $500 \mu$. Conidia acrogenous, cylindric, olive-brown, single, produced as an outgrowth of sterigmata, numerous, in groups of up to 15 or more, at apex of conidiophores, easily detached, 1 to 7 septate, slightly constricted at septa, varying in length from 18 to $92 \mu$ by 7.5 to $15 \mu$ in width, thick-walled. Sclerotia numerous in necrotic tissues of leaves and vines, subepidermal, imbedded in substrata, varying in diameter from 40 to $1000 \mu$, irregularly shaped, dark, semi-hard, not smooth.

\section{PATHOGENICITY}

Observations of artificial inoculation with conidia obtained from pure cultures of the parasite and from natural infections on leaves, followed by reisolations of the parasite, showed the constant association of the Acrothecium sp. in question and the disease.

Inoculations were conducted in a greenhouse with an air temperature fluctuating from $24^{\circ} \mathrm{C}$. to $37^{\circ} \mathrm{C}$, and outside under a half lath-shade plant house with an air temperature ranging from $\$ 6$ to $30^{\circ} \mathrm{C}$. Cuttings of B. rubra apparently free from natural infection, were obtained and rinsed several times under a faucet to remove dirt and possible conidia of the parasite that might have landed on them. The cuttings were placed with cut ends immersed in distilled water and in a three-salt nutrient solution. In this manner they were left for four weeks in a humid environment to allow for germination of conidia of the parasite if present on the leaves, and infection.

In August, the disease-free cuttings having several leaves, were inoculated with a suspension of conidia of the parasite taken from pure cultures of the organism. The conidia were sprayed over the leaves and vines of the cuttings with a De Vries atomizer. The cuttings after spraying were kept inside a large glass box with adjustable side doors and with inside shelves for keeping a thermograph and a hygrograph. The air temperature inside the glass box fluctuated from 26 to $35^{\circ} \mathrm{C}$. daily and the relative humidity was around $80 \%$. Control plants were similarly treated but not inoculated, spraying being done with distilled water only. Twelve cuttings were used in this test. A parallel test was conducted outside under the half-shade plant house.

Within a week after inoculation, the cuttings kept in the glass box showed symptoms of disease. Small yellowish lesions were evident on the leaves (Fig. 8). Seven days later, small reddish lesions were also evident on the vines. Cuttings kept outside under the lath-shade plant house were also showing the same symptoms of disease. The weather outside has been rather hot, $30^{\circ} \mathrm{C}$. in the shade, and the relative humidity very high, sometimes around $80 \%$, due to the frequency of rains and numerous cloudy days. 
After infection was noticed on the inoculated cuttings, half of them were taken out of the glass box and kept in a greenhouse with a relative humidity around $40 \%$, and a temperature range of $26^{\circ} \mathrm{C}$. to $35^{\circ} \mathrm{C}$. daily.

Observations of the infected cuttings kept inside the glass box and those in the greenhouse, showed that relative humidity of the environment is the most important factor for disease. The cuttings in the glass box showed constant enlargement of the leaf and vine lesions, culminating in blight. Cuttings outside the box in the greenhouse showed arrested development of lesions and a complete check of further infection and blight. It appeared therefore that under natural conditions the organism isolated and found parasitic on $B$. rubra, is favored by high relative humidity and high temperature. During the summer of 1943, the weather was hot and humid

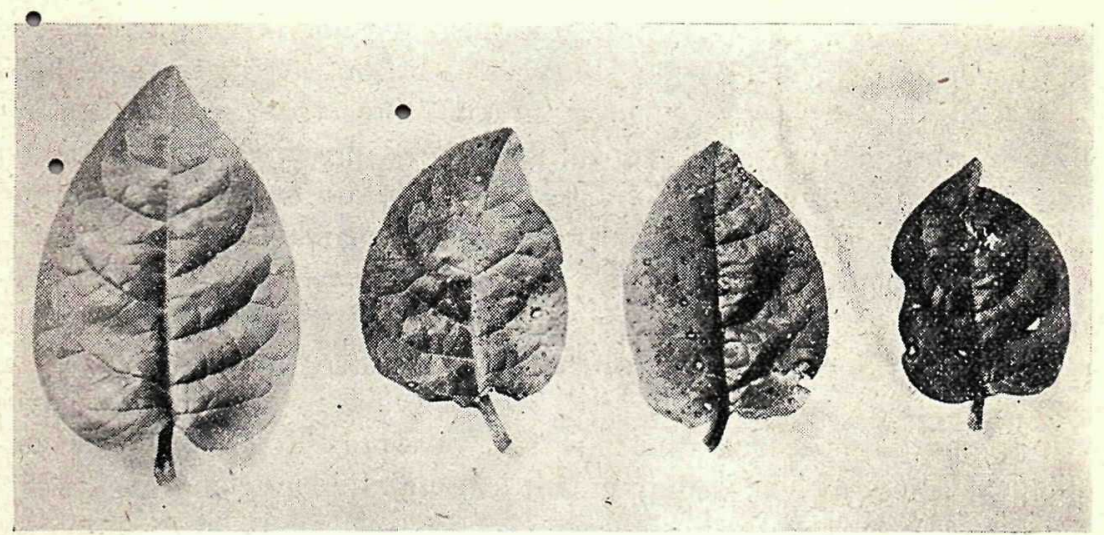

FIG. 8. Artificially infected leaves of Basella rubra L., showing characteristic lesions produced by Acrothecium basellae. Uninoculated leaf at left. $\times \frac{1}{2}$.

conditions which undoubtedly favored the rapid spread of the disease. Abundant precipitation occurred and the temperature was high, the days were cloudy and muggy.

Plants in the WPA garden were grown on trellis and in an exposed place, which though windy, was particularly humid due to the humid air coming from nearby hills. In this environment very copious sporulation occurred asshown by periodic microscopic examination of leaves. Periodic examination of recently infected leaves also revealed the manner of fungal penetration of healthy tissues. Penetration was observed to occur either through the cells or between the cells or by way of stomata. 'In some of the germinating spores, appresoria-like structures were noticed before penetrating pecks were produced.

Conidia were evidently blown from place to place. Infections occurred 
more abundantly on the leeward side of the field. Leaf lesions were very abundant in mature and in newly formed leaves.

Microscopic examination of infected leaves that had fallen on the ground revealed the profuseness of sclerotia formation in the dead leaf tissues. It appears, therefore, that the parasite is able to pass its saprogenic cycle in the soil in the form of sclerotia. With the advent of favorable weather conditions these sclerotia are liable to germinate and sporulate. When dead leaves with abundant sclerotia were placed in moist chambers the latter were found to germinate. The mycelial growth sporulated in few days. This tends to confirm the supposition that saprogenesis occurs in nature in the form of sclerotia.

\section{CONTROL}

The value of spraying with Bordeaux was determined before attempting to try other fungicides. Weekly spraying with Bordeaux formulae 3-3-50 and 4-4-50, proved very satisfactory in controlling the disease. Best results were obtained with the stronger formula. Spraying was initiated on September and continued until November. The summer was very humid and hot, characterized by frequent rainy and cloudy days.

One row of plants, approximately 24 feet long was selected on the leeward side of the infected field. In this manner there was a good chance for a constant blowing of conidia from the infected windward side of the field. At the end of eight weeks of weekly sprayings new shoots and leaves were produced almost free from infection. Unsprayed plants left as control on the same row, showed abundant leaf and vine lesions.

The disease was found to be checked by dry spells. Relative humidity is considered the most important factor determining the incidence of the disease in Puerto Rico, where high temperatures are registered the year round. Therefore, spraying was necessary only during humid weather. Plowing under infected plant debris, and crop rotation are also recommendations which might help in the prevention of the disease.

\section{SUMMARY}

A leaf spot of Basella rubra L., caused by an Acrothecium species, not previously recognized in Puerto Rico nor probably elsewhere as a parasite of the above mentioned plant, is described in this paper. The parasite was found to produce leaf lesions within 5 to 7 days after inoculation with conidia obtained from pure cultures of the organism. Vine lesions were somewhat delayed in their appearance.

Humid atmospheric condition accompanied by relatively high temperature, favored the incidence of the disease, as shown by pathogenicity tests conducted under glass house and field conditions. The foliage of heavily 
infected plants blighted in humid environment and became useless for consumption.

Weekly sprayings with Bordeaux, 3-3-50 and 4-4-50, were found successful in controlling the disease, the latter formula giving better results under persistent humid conditions of the environment.

RESUMEN EN ESPAÑOL

Durante el verano del 1943 se observó en una siembra de Espinacas del País (Basella rubra L.) una chamusquina de las hojas, apareciendo ésta primeramente en forma de pequeñas manchas rojizas que al agrandarse y venir en contacto formaban mancharones de tejidos necróticos descoloridos.

El ambiente en que crecían dichas plantas demostró ser propicio para el desarrollo de la enfermedad. El tiempo fué húmedo, cálido y los días se presentaron lluviosos y generalmente nublados. Un examen microscópico de las lesiones en las hojas reveló la abundancia de conidióforos extremadamente largos y matados en esterígmatas en forma de ramilletes de uvas. De estas esterígmatas produjéronse esporas alargadas, cilíndricas, tabicadas hasta 7 veces, trasversalmente, y formando en conjunto un ramillete. La morfología de este organismo demostró pertenecer al género Acrothecium. Por considerarse una especie hasta el presente no informada. en $B$. rubra, se describe en este trabajo como una especie nueva, dándosele el nombre de Acrothecium basellae.

$\mathrm{Al}$ hacerse cultivos con esporas tomadas de lesiones en las hojas, como así también de esclerocios tomados de tejidos necróticos en dichas hojaș, se aisló invariablemente el susodicho organismo. Pruebas de patogenicidad realizadas con conidios, del organismo producidos en cultivo puro demonstraron incontrovertiblemente su virulencia y única relación con la enfermedad en cuestión. Los síntomas producidos fueron aquéllos anteriormente observados ocurriendo naturalmente en las hojas. El examen microscópico de las lesiones producidas por inoculación artificial con conidios tomados de cultivos puros, reveló la presencia del organismo en los tejidos parasitados y la morfología del mismo vino a corroborar su identidad como el que fuera aislado repetidamente de lesiones naturales en las hojas. Al hacerse cultivos de tejidos de lesiones de hojas artificialmente inoculadas se recuperó invariablemente el parásito.

El examen necroscópico de las lesiones en las hojas mostró la presencia. de abundantes esclerocios en los tejidos subepidermales. Las observaciones hechas hacen creer que el parásito perdura saprogénicamente en residuos de hojas y tallos enfermos. Cuando el ambiente es propicio germinan dichós esclerocios; producen nuevamente conidios y la enfermedad vuelve a aparecer.

Ensayos realizados con caldo bordelés (fórmulas 3-3-50 y 4-4-50) 
demostraron que la enfermedad se puede combatir efectivamente con este fungicida. La fórmula más concentrada dió mejores resultados, particularmente en tiempo extremadamente húmedo. Las pulverizaciones se espaciaron cada 7 días, encontrándose que así repartidas eran suficientes para combatir la enfermedad.

Pruebas hechas en invernáculos demostraron como, en un ambiente marcadamente seco ( $40 \%$ de humedad relativa), se retardaba marcadamente el aumento en tamaño de las lesiones y disminuía el número de éstas. En tiempo marcadamente seco no es de esperarse que sea tan severa la enfermedad; bastaría, si fuere necesario, pulverizar con bordelés de vez en cuando.

\section{REFERENCES}

(1) Ashford, Bailey K, and Ciferri, Raffaele, A new variety of Acrothecium obovatum. Mycologia 22 (4), 180-188. 1930. illus.

(2) Cooke and Ellis, New Jersey Fungi. Grevilleae, 5, 49-55. 1876. illus.

(3) Ferraris, T., Fungi Imperfecti. In Rab. Krypt. Fl., 1 (8), 1-852. 1904-07. (9), 1-984. 1907-10.

(4) Mason, E. W., Annoted Account of Fungi Received at the Imperial Bureau of Mycology. List II (Fascile I), 1-43. 1928.

(5) Monoranjan Mitra, Morphology and parasitism of Acrothecium penniseti n. sp. (A new disease of Pennisetum Typhoideum) Mem. Dept. Agric. in India, Agric. Res. Inst. Pusa, Bot. Series, Vol. XI, No. 3. 1921. illus.

(6) Preuss, C. G. T., Ulbersicht untersuchter Pilze, leisonders aus der Umgegend von Hayerswerda Sinneae, 24, 99-153. 1851.

(7) Preuss, C. G. T., In Sturm Deuts. Fl. Abt. III, Heft. 29-30. 1851.

(8) Saccardo, P. A., Sylloge Hypomycetum. Syll. Fung, 4, 1-808. 1886.

(9) Stevenson, John A., Foreign Plant Diseases. U. S. Dept. of Agr., Contr. Fed. Hort. Board. Government Printing Press. Washington, D. C., 1926.

(10) Tehon, Leon R., Studies of Some Porto Rican Fungi. Bot. Gaz., 67, 509-512. 1919. illus. 